Volume. 7 Nomor. 1, Oktober 2019. p - 2354-8649 I e - 2579-5767

Open Access at: http://ojs.umrah.ac.id/index.php/selat

DOI: https://doi.org/10.31629/selat.v7i1.1521

\title{
PERLINDUNGAN HUKUM BAGI KREDITUR ATAS OBYEK JAMINAN BERUPA BANGUNAN TANPA TANAH DALAM PERSPEKTIF ASAS PEMISAHAN HORIZONTAL
}

\author{
Hatta Isnaini Wahyu Utomo \\ Fakultas Hukum Universitas Yos Sudarso Surabaya \\ Jl. Dukuh Kupang Barat I No. 216-218, Surabaya \\ Email : hatta.isnaini@yahoo.com
}

\begin{abstract}
The principle of horizontal scheiding that applies in the Land Law in Indonesia gives birth to problems especially those relating to the Law of Guarantees. The separation that allows land and buildings that stand on it is owned by different legal subjects. This condition can make it difficult for the creditor's position to execute if the debtor as the land owner or as the owner of the building above the land is in default. The author in this study wants to examine and analyze further the characteristics of building ownership that are separate from land ownership based on the principle of horizontal separation and the form of legal protection for creditors on collateral objects in the form of buildings that are separate from the ownership of their land. The research method used is normative legal research, namely legal research carried out by examining library materials or secondary legal materials while the problem approach is carried out using a legal approach and conceptual approach. The results of the study show that the principle of horizontal scheiding in Indonesian land law provides a separation between the ownership of land and buildings attached to the land which has separate legal status from each other and is proven by a land ownership certificate or a building ownership certificate. Legal protection to creditors on collateral objects in the form of buildings whose ownership is separate from land can be obtained from a statement made by the landowner that the concerned person will not guarantee the land to other creditors other than the fiduciary guarantee recipient who receives collateral in the form of fiduciary buildings on said land.
\end{abstract}

Keywords; Land, Principle of Horizontal Scheiding, Guarantee.

\begin{abstract}
Abstrak
Asas pemisahan horizontal yang berlaku dalam Hukum Tanah di Indonesia melahirkan permasalahan khususnya yang berkaitan dengan Hukum Jaminan. Adanya pemisahan yang memungkinan tanah dan bangunan yang berdiri di atasnya dimiliki oleh subyek hukum yang berbeda. Kondisi tersebut dapat menyulitkan posisi kreditur untuk melakukan eksekusi apabila debitur sebagai pemilik tanah atau sebagai pemilik bangunan yang ada di atas tanah tersebut wanprestasi. Penulis dalam penelitian ini ingin menelaah dan menganalisa lebih lanjut tentang karakteristik kepemilikan bangunan yang terpisah dari kepemilikan tanah berdasarkan asas pemisahan horizontal dan bentuk perlindungan hukum bagi kreditur atas obyek jaminan berupa bangunan yang terpisah dari kepemilikan tanahnya. Metode penelitian yang digunakan adalah penelitian hukum normatif, yaitu penelitian hukum yang dilakukan dengan cara meneliti bahan pustaka atau
\end{abstract}


bahan hukum sekunder sedangkan pendekatan masalah dilakukan dengan menggunakan pendekatan undang-undang dan pendekatan konseptual. Hasil penelitian menunjukkan bahwa pemberlakuan asas pemisahan horizontal di dalam hukum pertanahan Indonesia memberikan pemisahan antara kepemilikan tanah dan bangunan yang melekat di atas tanah tersebut yang memiliki status hukum terpisah satu sama lainnya dan dibuktikan dengan sertifikat kepemilikan tanah atau sertifikat kepemilikan bangunan. Perlindungan hukum kepada kreditur atas obyek jaminan berupa bangunan yang kepemilikannya terpisah dengan tanah dapat diperoleh dari surat pernyataan yang dibuat oleh dari pemilik tanah bahwa yang bersangkutan tidak akan menjaminkan tanah dimaksud kepada kreditur lain selain penerima jaminan fidusia yang menerima jaminan berupa fidusia bangunan di atas tanah dimaksud.

Kata Kunci; Tanah, Asas Pemisahan Horizontal, Jaminan.

\section{PENDAHULUAN}

Tanah secara hukum memegang peranan kunci bagi kehidupan manusia, baik secara individual/perorangan maupun secara sosial/kemasyarakatan. Peranan kunci, karena tanah dapat menentukan keberadaan dan keberlangsungan hubungan dan perbuatan hukum, baik bagi diri individu maupun implikasinya bagi orang lain. Salah satu aspek yang penting di dalam hukum tanah adalah tentang hubungan hukum antara tanah dengan benda lain yang melekat padanya. Kepastian hukum akan kedudukan hukum dari benda yang melekat pada tanah itu sangat penting karena hal ini mempunyai pengaruh yang luas terhadap segala hubungan hukum yang menyangkut tanah dan benda yang melekat padanya.

Di dalam hukum tanah dikenal ada 2 (dua) asas yang satu sama lain bertentangan yaitu yang dikenal dengan asas pelekatan Vertikal (verticale accessie beginsel) yang bersumber pada Hukum Tanah berdasarkan Kitab Undang-Undang Hukum Perdata dan asas pemisahan horisontal (horizontale scheiding beginsel) yang bersumber pada Hukum Adat. ${ }^{1}$ Asas pemisahan horizontal adalah kebalikan dari asas pelekatan vertikal yang mengatakan bangunan dan tanaman merupakan satu kesatuan dengan tanah. Sebaliknya, asas pemisahan horizontal menyatakan bangunan dan tanaman bukan merupakan bagian dari tanah. Konsekuensinya hak atas tanah tidak dengan sendirinya maliputi pemilikan bangunan dan tanaman yang ada di atasnya.

\footnotetext{
1 Djuhaendah Hasan, Lembaga Jaminan Kebendaan Bagi Tanah Dan Benda Lain yang Melekat Pada Tanah Dalam Konsepsi Penerapan Asas Pemisahan Horisontal, (Bandung: Citra Aditya Bakti, 1996), hlm. 65.
} 
Sebelum berlakunya UUPA kedua asas ini diterapkan secara bersamaan karena pada saat itu Hukum Tanah masih bersifat dualistis. Sejak berlakunya UUPA maka ketentuan Buku II KUH Perdata sepanjang mengenai bumi, air serta kekayaan di dalamnya telah dicabut, kecuali tentang hipotik. Dengan demikian maka yang diberlakukan dalam Hukum Tanah Nasional adalah asas pemisahan horisontal (horizontale scheiding beginsel) karena dalam Pasal 5 UUPA disebutkan bahwa Hukum agraria yang berlaku atas bumi, air dan ruang angkasa ialah Hukum Adat.

Sebagaimana diketahui Hukum Tanah Nasional didasarkan pada hukum adat, yang menggunakan asas pemisahan horizontal. Sehubungan dengan itu, maka dalam kaitannya dengan bangunan, tanaman, dan hasil karya tersebut, Hukum Tanah Nasional menggunakan juga asas pemisahan horizontal. Dalam rangka asas pemisahan horizontal, benda-benda yang merupakan satu kesatuan dengan tanah menurut hukum bukan merupakan bagian dari tanah yang bersangkutan. Oleh karena itu, setiap perbuatan hukum mengenai hak-hak atas, tidak dengan sendirinya meliputi benda-benda tersebut. Namun, demikian, penerapan asas-asas hukum adat tidaklah mutlak, melainkan selalu memperhatikan dan disesuaikan dengan perkembangan kenyataan dan kebutuhan dalam masyarakat yang dihadapinya. ${ }^{2}$

Berlakunya asas pemisahan horizontal melahirkan pula beberapa permasalahan khususnya yang berkaitan dengan Hukum Jaminan. Dengan adanya pemisahan yang memungkinan tanah dan bangunan yang berdiri di atasnya dimiliki oleh subyek hukum yang berbeda. Kondisi tersebut dapat menyulitkan posisi kreditur untuk melakukan eksekusi apabila debitur sebagai pemilik tanah atau sebagai pemilik bangunan yang ada di atas tanah tersebut wanprestasi. Dalam hal ini perlu dirumuskan suatu bentuk perlindungan hukum bagi kreditur apabila antara tanah dan bangunan yang berada diatasnya dimiliki oleh subyek hukum yang berbeda.

Dari uraian diatas dirumuskan permasalahan sebagai berikut: a) karakteristik kepemilikan bangunan yang terpisah dari kepemilikan tanah berdasarkan asas pemisahan horizontal; dan b) bentuk perlindungan hukum bagi kreditur atas obyek jaminan berupa bangunan yang terpisah dari kepemilikan tanahnya.

2 Gabriella Yulistina Aguw, "Kajian Yuridis Asas Pemisahan Horisontal Dalam Hak Tanggungan Atas Tanah", Jurnal Lex et Societatis, 65, no. 6 (2017): 1-172. hlm. 97 
Penelitian ini menggunakan metode penelitian hukum normatif yang dilakukan untuk mencari pemecahan masalah atas permasalahan hukum yang ada. Pendekatan penelitian yang digunakan adalah pendekatan undang-undang (statute approach) dan pendekatan konseptual (conceptual approach).

\section{PEMBAHASAN}

\subsection{Karakteristik Kepemilikan Bangunan yang Terpisah dari Kepemilikan} Tanah Berdasarkan Asas Pemisahan Horizontal

Hukum Pertanahan yang berlaku secara umum mengenal adanya perbedaan antara asas pelekatan Vertikal (verticale accessie beginsel) dan asas pemisahan horisontal (horizontale scheiding beginsel) yang memberikan pengaruh dalam bentuk kewenangan dan kepemilikan tanah. ${ }^{3}$ Asas perlekatan (acessie) yang menguraikan pengertian bahwa tanah tidak hanya terbatas pada permukaan bumi saja tetapi juga apa yang berada di bawah dan diatasnya karena seluruhnya adalah satu kesatuan yang melekat dan tidak dapat dipisahkan. Pemilik hak atas tanah diberikan kewenangan yang sejalan dengan pengertian tersebut, artinya, kewenangan dan kepemilikan hak atas tanah bukan hanya sebatas permukaan tanah saja melainkan juga yang terkandung di bawahnya pula yang melekat dan berdiri di atasnya. Kewenangan yang begitu luas dalam pemilikan tanah yang menggunakan asas perlekatan tersebut didasarkan pada asas yang dikenal dalam hukum Romawi, yaitu supefices cedit solo, dan selaras pula dengan adagium hukum yang menyatakan cujus est solum, ujus est usque ad coelum et de inferos yang memiliki arti bahwa barang siapa memiliki tanah, dia juga memiliki segala apa yang ada di atasnya sampai ke surga, dan segala apa yang dibawahnya sampai ke pusat bumi. ${ }^{4}$

Sedangkan asas yang kedua adalah asas pemisahan horizontal. Dalam asas ini, pengertian tanah hanya meliputi permukaan tanah saja sehingga apa yang melekat atau berdiri di atasnya dan apa yang terkandung di bawahnya bukanlah satu kesatuan melainkan bentuk- bentuk yang terpisah. Menurut Ter Haar asas ini, menurutnya, tanah terpisah dari segala sesuatu yang melekat padanya atau

\footnotetext{
${ }^{3}$ Boedi Harsono, Hukum Agraria Indonesia (Sejarah Pembentukan Undang-Undang Pokok Agraria Isi dan Pelaksanaannya), (Jakartta: Djambatan, 2008), hlm. 20

4 Eman Ramelan, "Pidato Pengukuhan : Asas Pemisahan Horizontal Dalam Hukum Tanah Nasional", September 13, 2018
} 
pemilikan atas tanah terlepas dari benda yang berada di atas tanah itu, sehingga pemilik atas tanah dan bangunan yang berada di atasnya dapat berbeda. ${ }^{5}$ Mengacu kepada pengertian dari asas pemisahan horizontal dan pendapat Ter Haar, pemberian kewenangan kepada pemegang hak atas tanah hanya sebatas permukaan tanahnya saja sedangkan bangunan atau apapun yang melekat di atas tanah tersebut berbeda hak kepemilikannya dengan tanah tersebut dan hal ini membuka kemungkinan bahwa individu yang menjadi pemegang hak atas benda yang melekat di atas tanah berbeda dengan individu yang memegang hak atas tanah.

Di Indonesia pengaturan mengenai asas perlekatan vertikal yang pernah berlaku sebelum era UUPA berpedoman pada ketentuan dalam KUHPerdata. Asas perlekatan ini secara tegas dinyatakan dalam KUHPerdata khususnya pada Pasal 500, Pasal 571, dan Pasal 601 yang menyatakan bahwa hak milik atas sebidang tanah mengandung pula kepemilikan atas segala sesuatu yang ada di atas tanah maupun di dalam tanah tersebut. Kata lain, kepemilikan atas tanah meliputi pula kepemilikan atas bangunan yang ada diatasnya, karena bangunan merupakan bagian dari tanah tersebut dan bangunan yang didirikan di atas tanah kepunyaan pihak lain akan menjadi milik pemilik tanah. ${ }^{6}$

Asas pelekatan vertikal yaitu asas yang mendasarkan pemilikan tanah dan segala benda yang melekat padanya sebagai suatu kesatuan yang tertancap menjadi satu. Dalam hukum tanah Negara-negara yang menggunakan apa yang disebut Asas Accessie atau Asas pelekatan, bangunan dan tanaman yang ada di atas dan merupakan satu kesatuan dengan tanah, merupakan bagian dari tanah yang bersangkutan. Hak atas tanah dengan sendirinya, karena hukum, meliputi juga pemilikan bangunan dan tanaman yang ada di atas tanah yang dihaki. Kecuali kalau ada kesepakatan lain dengan pihak yang membangun atau menanamnya (Pasal 500 dan 571 KUH Perdata). ${ }^{7}$ Perbuatan hukum mengenai tanah dengan sendirinya meliputi tanaman dan bangunan yang ada di atasnya. Umumnya bangunan dan tanaman yang ada di atas tanah adalah milik yang empunya tanah.

5 Ibid, hlm. 54

${ }^{6}$ Dyah Devina Maya Ganindra dan Faizal Kurniawan, "Kriteria Asas Pemisahan Horizontal Terhadap Penguasaan Tanah Dan Bangunan”, Jurnal Yuridika 32, no. 2 (2017): 1-182), hlm. 72

7 Boedi Harsono, Op. Cit., hlm. 20. 
Pada negara-negara yang menganut asas perlekatan (accesie) memberikan arti tentang tanah dengan sangat luasnya, tidak saja terbatas pada permukaan bumi, tapi juga termasuk apa yang ada dibawahnya serta segala sesuatu yang ada di atasnya. Pengertian tanah yang demikian ini oleh Peter Butt dikatakan tidak hanya meliputi the surface of the earth tetapi juga everything under it and over it. Dengan demikian tanah tidak hanya meliputi permukaan bumi saja, melainkan berupa inverted pyramid having its tip or apex, at the center of the earth, extending outward through the surface of the earth at the boundary lines of the tract, and continuing to the heaven. ${ }^{8}$

Asas perlekatan yang dianut hukum tanah kolonial sangat bertentangan dengan hukum tanah adat dimana hukum tanah adat menganut asas pemisahan horizontal. Asas pemisahan horizontal yang dianut hukum tanah adat menyatakan bahwa bangunan, tanaman, dan benda-benda bersifat ekonomis lainnya yang ada di atas tanah bukanlah merupakan bagian dari tanah. Kata lain, kepemilikan atas tanah tidak meliputi kepemilikan atas bangunan diatasnya, bangunan berada di bawah kepemilikan pihak yang membangun bangunan tersebut. ${ }^{9}$ Dalam hukum Indonesia dimungkinkan pemilikan secara pribadi bagian-bagian bangunan, karena hukum Indonesia menggunakan asas pemisahan horizontal, yaitu asas hukum adat yang merupakan dasar Hukum Tanah Nasional. ${ }^{10}$ Berdasarkan asas pemisahan horizontal pemilikan atas tanah dan benda-benda yang berada di atas tanah itu adalah terpisah. Pemilikan atas tanah terlepas dari benda-benda yang ada di atas tanah, sehingga pemilik hak atas tanah dan pemilik atas bangunan yang berada di atasnya dapat berbeda. $^{11}$

Asas pemisahan horizontal hak-hak atas tanah yang merupakan sifat asli hak-hak dalam hukum adat, tetap dipertahankan tetapi disesuaikan dengan kenyataan kebutuhan masyarakat masa kini.Hak atas tanah tidak meliputi pemilikan atas bangunan yang ada di atasnya. Bangunan, tanaman dan benda-benda lain yang ada di atas suatu bidang tanah adalah milik pihak yang membangun atau yang menanam,

\footnotetext{
8 Peter Butt, Hand Book of Singapore Land Law, (Singapore: Butterworths, 1986), hlm. 192.

${ }^{9}$ Hatta Isnaini Wahyu Utomo, "Hukum Tanah Nasional : Bahan Diskusi Dalam Persiapan Menghadapi Ujian Pejabat Pembuat Akta Tanah 2017”, Makalah, disampaikan pada acara Persiapan Menghadapi Ujian PPAT 2017, Universitas Narotama Surabaya, Oktober 2017, hal. 24

10 Boedi Harsono. Loc.Cit

11 Imam Sudiyat, Hukum Adat Sketsa Asas, (Yogyakarta: Liberty, 1981), hlm. 54
} 
baik pihak itu pemegang hak atas tanahnya sendiri atau bukan, kecuali kalau ada perjanjian sebaliknya. Maka perbuatan hukum mengenai tanah tidak dengan sendirinya meliputi bangunan, tanaman dan/atau benda-benda lain yang ada di atasnya, kalau hal itu tidak secara tegas dinyatakan. ${ }^{12}$ Namun demikian penerapan asas-asas hukum adat tidaklah mutlak melainkan selalu memperhatikan dan disesuaikan dengan perkembangan kenyataan dan kebutuhan dalam masyarakat yang dihadapinya. 13

UUPA merupakan perwujudan upaya maksimal bangsa Indonesia untuk membebaskan diri dari ketergantungan dengan bangsa lain di bidang hukum pertanahan. Sebelum diberlakukannya UUPA Indonesia menganut dua hukum tanah yang berbeda, yakni; Hukum Tanah Kolonial yang dituangkan dalam Burgelijk Wetbook (selanjutnya disebut dengan BW) dan Hukum Tanah Adat yang bersumber dari hukum adat. Asas pemisahan horizontal ini adalah asas yang saat ini diberlakukan dalam Hukum Pertanahan Nasional, mengesampingkan asas perlekatan yang telah dijelaskan sebelumnya. Dalam asas pemisahan horizontal, bangunan dan tanaman yang ada di atas tanah bukanlah merupakan bagian dari tanah sehingga kepemilikan bangunan dan tanaman di atas sebidang tanah tidak serta merta jatuh kepada si pemilik tanah. ${ }^{14}$

Perbuatan hukum mengenai tanah tidak dengan sendirinya meliputi bangunan dan tanaman milik si pemilik tanah diatasnya. Jika perbuatan hukum terhadap tanah dimaksudkan untuk meliputi pula bangunan dan tanamannya, maka hal ini harus secara tegas dinyatakan dalam akta yang membuktikan dilakukannya perbuatan hukum yang bersangkutan. Asas pemisahan horizontal sebagai asas yang dianut dalam Hukum Pertanahan Nasional dapat ditemukan dalam ketentuan Pasal 44 ayat 1 UUPA, yaitu "Seorang atau suatu badan hukum mempunyai hak sewa atas tanah, apabila ia berhak menggunakan tanah milik orang lain untuk keperluan bangunan, dengan membayar kepada pemiliknya sejumlah uang sebagai uang sewa”. Penerapan

12 Boedi Harsono, Menuju Penyempurnaan Hukum Tanah Nasional Dalam Hubungannya Dengan TAP MPR RI IX/MPR/2001, (Jakarta: Universitas Trisakti, 2003), hlm. 73

13 Betty Rubiati, Yani Pujiwati, Mulyani Djakaria, "Asas Pemisahan Horizontal Dalam Kepemilikan Hak Atas Tanah Dan Bangunan Satuan Rumah Susun Bagi Masyarakat Berpenghasilan Rendah (MBR)", Jurnal Sosiohumaniora 17, no. 2 (2015): 1-148, hlm. 99

${ }^{14}$ Hatta Isnaini Wahyu Utomo, Memahami Pelaksanaan Tugas Jabatan Pejabat Pembuat Akta Tanah, (Yogyakarta: Phoenix Publisher, 2019), hlm. 27 
asas pemisahan horizontal terdapat dalam Hak Sewa untuk Bangunan dimana seseorang atau badan hukum menyewa tanah yang merupakan milik orang lain dalam keadaan tanah tersebut kosong atau tidak ada bangunannya dengan membayar sejumlah uang sebagai uang sewa yang besarnya ditetapkan atas dasar kesepakatan bersama dan untuk jangka waktu tertentu, dimana dalam jangka waktu tersebut si penyewa diberikan hak untuk mendirikan bangunan. Dalam contoh diatas, terdapat pemisahan secara horizontal antara kepemilikan tanah dengan kepemilikan bangunan yang ada diatasnya, dimana tanahnya merupakan milik pemilik tanah dan bangunannya merupakan milik si penyewa tanah selaku orang yang mendirikan bangunan tersebut. ${ }^{15}$

Pemberlakuan asas pemisahan horizontal di dalam hukum pertanahan Indonesia memberikan pemisahan antara kepemilikan tanah dengan apa yang melekat dibawahnya dan berada di atas tanah tersebut, hanya yang langsung berhubungan dengan penggunaan tanah saja yang dapat dimanfaatkan. Hal ini membatasi kewenangan pemilik hak atas tanah dalam memanfaatkan tanah yang dimilikinya, karena pemanfaatan apa yang terkandung di dalam tanah dan yang melekat di atasnya harus dapat dibuktikan bahwa memang dan hanya yang berkaitan dengan penggunaan tanah tersebut.

Tanah dan bangunan yang berdiri diatasnya masing-masing didaftarkan secara terpisah sehingga status hukum tanah sebagai benda tetap yang didaftarkan serta benda-benda yang melekat padanya memiliki status hukum terpisah satu sama lainnya. Oleh karena itu kedua benda tersebut dapat dijadikan obyek dari perbuatan hukum yang terpisah. Dalam artian penjaminan atas tanah tidak serta merta akan mengikat benda-benda yang ada di atasnya. Mengingat tanah dan bangunan itu merupakan bagian yang terpisah, maka keduanya juga merupakan obyek pendaftaran yang terpisah pula. Dengan demikian akan dapat dibedakan antara sertipikat pemilikan tanah dan sertipikat pemilikan bangunan.

Ketentuan yang mengatur tentang alat bukti hak atas tanah dijumpai dalam Peraturan Pemerintah Nomer 24 Tahun 1997 tentang Pendaftaran Tanah. Pasal 32 ayat 1 nya menyatakan bahwa sertipikat merupakan surat tanda bukti hak yang berlaku sebagai alat pembuktian yang kuat mengenai data fisik dan data juridis

15 Dyah Devina Maya Ganindra dan Faizal Kurniawan, Op. Cit., hlm. 73 
sesuai dengan data yang ada dalam surat ukur dan buku tanah hak yang bersangkutan. Sertipikat yang demikian ini dibuat dan dikeluarkan oleh Kantor Peratanahan. Pengaturan alat bukti bangunan mendapatkan pengaturan dalam Undang Undang Nomor 28 Tahun 2002 Tentang Bangunan Gedung serta Peraturan Pemerintah Nomor 36 Tahun 2005 Tentang Peraturan Pelaksanaan Undang Undang Nomor 28 Tahun 2002 Tentang Bangunan Gedung. Pasal 7 dan 8 dari Undang Undang Nomor 28 Tahun 2002 menyatakan bahwa bangunan gedung harus memenuhi persyaratan administratif yang meliputi :

a. status hak atas tanah, dan/atau izin pemanfaatan dari pemegang hak atas tanah;

b. status kepemilikan bangunan gedung; dan

c. izin mendirikan bangunan gedung.

Pasal 12 ayat 1 Peraturan Pemerintah Nomor 36 Tahun 2005 menentukan bahwa status kepemilikan bangunan gedung dibuktikan dengan surat bukti kepemilikan bangunan gedung yang dikeluarkan oleh Pemerintah daerah, kecuali bangunan gedung dengan fungsi khusus (untuk reaktor nuklir, kepentingan hankam) dikeluarkan oleh Pemerintah Pusat. Surat bukti kepemilikan atas bangunan tersebut disebut dengan Surat Kepemilikan Bangunan Gedung (SKBG).

Dengan adanya dua alat bukti tersebut di atas (bukti kepemilikan hak atas tanah dan bukti kepemilikan gedung), secara ideal akan memberikan opsi atau pilihan bagi pemiliknya untuk melakukan perbuatan hukum atas benda miliknya. Pemilik bisa memilih tanah atau bangunannya atau kedua-duanya sekaligus dipergunakan sebagai obyek dalam perbuatan hukum.

\subsection{Perlindungan Hukum Bagi Kreditur Atas Obyek Jaminan Berupa Bangunan Yang Terpisah Dari Kepemilikan Tanahnya}

Asas pemisahan horizontal yang saat ini diberlakukan dalam Hukum Tanah Nasional, mengesampingkan asas perlekatan yang telah dijelaskan sebelumnya. Dalam asas pemisahan horizontal, bangunan dan tanaman yang ada diatas tanah bukanlah merupakan bagian dari tanah sehingga kepemilikan bangunan dan tanaman di atas sebidang tanah tidak serta merta jatuh kepada si pemilik tanah. Perbuatan hukum mengenai tanah tidak dengan sendirinya meliputi bangunan dan 
tanaman milik si pemilik tanah diatasnya. Demikian pula dalam kaitannya dengan lembaga jaminan untuk tanah dan bangunan juga dibedakan menurut kedudukan masing-masing.

Jaminan merupakan terjemahan dari bahasa Belanda yaitu zekerheid atau cautie. Zekerheid atau cautie mencakup secara umum cara-cara kreditur menjamin dipenuhinya tagihannya, disamping pertanggung jawab umum debitur terhadap barang-barangnya. ${ }^{16}$ Pengertian Jaminan adalah "menjamin dipenuhinya kewajiban yang dapat dinilai dengan uang yang timbul dari suatu perikatan hukum. ${ }^{17}$ Oleh karena itu, hukum jaminan erat sekali kaitannya dengan hukum benda. ${ }^{18}$

Djuhaendah Hasan memberikan pengertian Jaminan sebagai sarana perlindungan bagi keamanan kreditur yaitu kepastian akan pelunasan hutang debitur atas pelaksanaan suatu prestasi oleh debitur atau oleh penjamin debitur. ${ }^{19}$ Sedangkan Rachmadi Usman memberikan pengertian jaminan sebagai suatu sarana perlindungan keamanan kreditur, yaitu kepastian akan pelunasan utang debitur atas pelaksanaan suatu prestasi oleh debitur atau oleh penjamin debitur. ${ }^{20}$

Pada prinsipnya menurut hukum segala harta kekayaan debitur akan menjadi jaminan bagi perutangannya dengan semua kreditur. Pasal 1131 BW menyatakan, bahwa segala kebendaan si berutang, baik yang bergerak maupun yang tak bergerak, baik yang sudah ada maupun yang baru akan ada dikemudian hari, menjadi tanggungan untuk segala perikatannya perseorangan. Dari Pasal 1131 BW tersebut, berarti seluruh harta kekayaan milik debitur akan menjadi jaminan pelunasan atas utang debitur kepada semua kreditur. Kekayaan debitur dimaksud meliputi benda bergerak maupun benda tetap, baik yang sudah ada pada saat perjanjian utang piutang diadakan maupun yang baru akan ada dikemudian hari yang akan menjadi milik debitur setelah perjanjian utang piutang diadakan.

Jaminan dibagi menjadi jaminan umum dan jaminan khusus. Jaminan khusus dibagi lebih lanjut menjadi jaminan kebendaan dan perorangan. Selanjutnya jaminan

\footnotetext{
${ }^{16}$ Herowati Poesoko, Parate execcutie Obyek Hak Tanggungan (inkonsistensi, Konflik Norma dan Kesesatan Penalaran dalam UUHT), (Yogyakarta: LaksBang PRESSind, 2008), hlm. 31.

17 Ibid, hlm. 32.

18 Mariam Darus Badrulzaman, Bab-bab Tentang Credietverband, Gadai dan Fidusia, (Bandung: Alumni, Bandung, 1987), hlm. 227-265.

19 Djuhaendah Hasan, Op.Cit., hlm. 233. hlm. 61.

20 Rachmadi Usman, Aspek-aspek Hukum Perbankan di Indonesia, (Jakarta: Gramedia Pustaka Utama, 2001),
} 
kebendaan dibagi menjadi jaminan benda bergerak dan jaminan benda tetap. Jaminan benda bergerak dibagi menjadi gadai dan fidusia, sedangkan jaminan benda tetap dibagi menjadi hak tanggungan atas tanah dan fidusia.

Agus Yudha Hernoko, jaminan khusus yang paling sering digunakan adalah jaminan kebendaan berupa tanah. Penggunaan tanah sebagai jaminan kredit didasarkan pada pertimbangan bahwa tanah paling aman dan mempunyai nilai ekonomis yang relatif tinggi. ${ }^{21}$ Pendapat serupa dikemukakan oleh Retnowulan yang menyatakan bahwa lembaga jaminan yang oleh lembaga perbankan dianggap paling efektif dan aman adalah tanah dengan jaminan hak tanggungan. Hal ini didasarkan pada kemudahan dalam identifikasi obyek hak tanggungan, jelas dan pasti eksekusinya serta mendahulukan pembayaran dari hasil pelelangan tanah kepada krediturnya. ${ }^{22}$

Secara hukum, lembaga jaminan untuk tanah dan bangunan yang berada di atasnya berbeda. Hak Atas Tanah lembaga jaminannya adalah Hak Tanggungan seperti yang diatur dalam Undang Undang Nomor 4 Tahun 1996 Tentang Hak Tanggungan Atas Tanah Beserta Benda-Benda Yang Berkaitan Dengan Tanah (UUHT), sedangkan lembaga jaminan bangunan gedung dapat dilakukan lewat Fidusia menurut Undang Undang Nomor 42 Tahun 1999 Tentang Jaminan Fidusia (UUJF).

Menurut Sutan Remi Sjahdeni, Hak Tanggungan mempunyai tiga unsur, yaitu :

a. Hak Tanggungan merupakan hak jaminan untuk pelunasan utang;

b. Obyek Tak Tanggungan adalah hak atas tanah sesuai UUPA;

c. Hak Tanggungan dapat dibebankan pada hak atas tanah, tetapi dapat pula dibebankan berikut benda-benda lain yang merupakan satu kesatuan dengan tanah itu;

d. Utang yang dijamin harus suatu utang tertentu;

e. Menimbulkan kedudukan didahulukan atau diutamakan kepada kreditor tertentu terhadap kreditor-kreditor lain. ${ }^{23}$

\footnotetext{
${ }^{21}$ Agus Yudha Hernoko, "Lembaga Jaminan Hak Tanggungan Sebagai Penunjang Kegiatan Perkreditan Perbankan Nasional”, Makalah, Fakultas Hukum Universitas Airlangga Surabaya, 1998, hlm. 7

22 Retnowulan Sutantio, Penelitian Tentang Perlindungan Hukum Eksekusi Jaminan Kredit, (Jakarta: Badan Pembinaan Hukum Nasional (BPHN), 1999), hlm. 8

${ }^{23}$ Sutan Remy Sjahdeini, Hak Tanggungan Asas-Asas Ketentuan-Ketentuan Pokok Dan Masalah Yang Dihadapi Oleh Perbankan, (Bandung: Alumni, 1999), hlm. 27
} 
Pasal 4 ayat 4 UUHT menyatakan Hak Tanggungan dapat juga dibebankan pada hak atas tanah, berikut bangunan, tanaman, dan hasil karya yang telah ada atau akan ada yang merupakan satu kesatuan dengan tanah tersebut, dan yang merupakan milik pemegang hak atas tanah yang pembebanannya dengan tegas dinyatakan di dalam Akta Pemberian Hak Tanggungan yang bersangkutan. Mencermati isi dari ketentuan ini, jelas dinyatakan bahwa pembebanan terhadap hak atas tanah akan termasuk atau beserta benda-benda yang berkaitan dengan tanah, kalau pemilik hak atas tanah dan bendanya adalah subyek yang sama serta dinyatakan secara tegas dalam akta pembebannya.

Jika kepemilikan hak atas tanah dengan bendanya berada pada subyek yang berbeda, maka menurut pasal 4 ayat 5 UUHT, akta pembebannya tersebut harus ditandatangani secara bersama oleh subyek pemegang hak atas tanah dan pemilik benda-benda yang ada di atas tanah itu. Rumusan yang ada dalam ketentuan tersebut untuk mencegah adanya kesulitan dalam praktek eksekusi, ketika debitur melakukan wanprestasi atau tidak dapat memenuhi hutangnya pada kreditur. Tidaklah mudah menjual atau melelang tanahnya tanpa sekaligus menjual atau melelang bangunan beserta bangunan atau benda-benda lain yang berkaitan dengan tanah.

Lembaga jaminan yang digunakan atas kepemilikan bangunan yang terpisah dari kepemilikan tanahnya adalah jaminan fidusia. Fidusia atas bangunan tersebut dapat terjadi karena hukum tanah di Indonesia menganut prinsip asas pemisahan horizontal (horizontale scheiding). Adanya azas tersebut memungkinkan untuk terjadinya pemisahan kepemilikan antara pemilik tanah dengan pemilik bangunan. Dalam hal terjadi demikian, maka atas bangunan yang terpisah kepemilikannya tersebut dan didirikan di atas tanah hak yang tidak dapat dibebani dengan Hak, dapat dibebani dengan Jaminan Fidusia. Jadi fidusianya hanya atas bangunannya saja sedangkan tanahnya tetap bebas.

Pemberian jaminan berupa fidusia bangunan tersebut harus memperhatikan beberapa kondisi penting:

1. Harus ada persetujuan dari pemilik/pemegang hak atas tanah yang di bawahnya didirikan bangunan tersebut, yang menyatakan:

a. Menyetujui pemberian jaminan fidusia atas bangunan dimaksud 
b. Dalam hal terjadi eksekusi jaminan, maka pemilik tanah tidak akan menghalang-halangi proses eksekusi atas bangunan dimaksud.

2. Harus dilengkapi dengan Ijin Mendirikan Bangunan atas nama pemberi fidusia yang kepemilikannya terpisah dengan kepemilikan atas tanahnya.

3. Dilengkapi dengan perjanjian dan/atau kesepakatan bersama antara pemilik lahan dengan pemilik bangunan, bahwa kepemilikan bangunan memang berada di tangan pemberi fidusia selaku pemilik bangunan yang sah.

Fidusia atas bangunan tersebut tidak banyak dilakukan karena berpotensi terhadap suatu resiko apabila tanahnya berstatus tanah hak primer biasa, seperti hak milik, hak guna bangunan, dan lain sebagainya, maka ada kemungkinan tanah tersebut dijaminkan kepada kreditur yang berbeda oleh pemilik tanah yang berkenaan. Sehingga, dalam hal terjadi eksekusi atas tanah tersebut dapat terjadi tumpang tindih antara eksekusi atas tanah dengan eksekusi atas bangunannya. Selain itu kedudukan dari kreditur pemegang jaminan fidusia atas bangunannya pada waktu terjadinya eksekusi akan lebih lemah dari kedudukan kreditur pemegang hak tanggungannya.

Atas kondisi tersebut untuk memberikan perlindungan hukum bagi kreditur atas jaminan fidusia berupa bangunan yang kepemilkannya terpisah dari tanahnya maka dapat ditambahkan surat pernyataan dari pemilik tanah, bahwa yang bersangkutan tidak akan menjaminkan tanah dimaksud kepada kreditur lain selain penerima jaminan fidusia yang menerima jaminan berupa fidusia bangunan di atas tanah dimaksud. Dalam hal terjadi demikian, maka disarankan jaminan tersebut bersifat paripasu (cross collateral) antara fasilitas kredit yang dijamin dengan fidusia bangunan dengan fasilitas kredit yang dijamin dengan Hak tanggungan atas tanah yang berada di bawahnya.

\section{SIMPULAN}

Pemberlakuan asas pemisahan horizontal di dalam hukum pertanahan Indonesia memberikan pemisahan antara kepemilikan tanah dengan apa yang melekat dibawahnya dan berada di atas tanah tersebut. Tanah dan bangunan yang berdiri diatasnya masing-masing didaftarkan secara terpisah sehingga status hukunya terpisah satu sama lainnya. Dengan demikian akan dapat dibedakan antara sertipikat 
tanah dan sertipikat kepemilikan bangunan. Untuk memberikan perlindungan hukum kepada kreditur atas obyek jaminan berupa bangunan yang kepemilikannya terpisah dengan tanah, maka pada saat dibuatnya perjanjian dilengkapi pula surat pernyataan dari pemilik tanah, bahwa yang bersangkutan tidak akan menjaminkan tanah dimaksud kepada kreditur lain selain penerima jaminan fidusia yang menerima jaminan berupa fidusia bangunan di atas tanah dimaksud. Perlu dibuat satu peraturan yang secara khusus mengatur tata cara menjaminkan bangunan yang kepemilikannya terpisah dari tanahnya agar dapat memberikan kepastian hukum.

\section{DAFTAR PUSTAKA}

Aguw, Gabriella Yulistina, "Kajian Yuridis Asas Pemisahan Horisontal Dalam Hak Tanggungan Atas Tanah", Jurnal Lex et Societatis, 65, no. 6 (2017): 1-172.

Badrulzaman, Mariam Darus. Bab-bab Tentang Credietverband, Gadai dan Fidusia, Bandung: Alumni, Bandung, 1987

Butt, Peter. Hand Book of Singapore Land Law, Singapore: Butterworths, 1986

Ganindra, Dyah Devina Maya. Kurniawan, Faizal. "Kriteria Asas Pemisahan Horizontal Terhadap Penguasaan Tanah Dan Bangunan", Jurnal Yuridika 32, no. 2 (2017): 1-182), hlm. 72

Harsono, Boedi. Hukum Agraria Indonesia (Sejarah Pembentukan Undang-Undang Pokok Agraria Isi dan Pelaksanaannya), Jakartta: Djambatan, 2008

---. Menuju Penyempurnaan Hukum Tanah Nasional Dalam Hubungannya Dengan TAP MPR RI IX/MPR/2001, Jakarta: Universitas Trisakti, 2003

Hasan, Djuhaendah. Lembaga Jaminan Kebendaan Bagi Tanah Dan Benda Lain yang Melekat Pada Tanah Dalam Konsepsi Penerapan Asas Pemisahan Horisontal, Bandung: Citra Aditya Bakti, 1996

Hernoko, Agus Yudha. "Lembaga Jaminan Hak Tanggungan Sebagai Penunjang Kegiatan Perkreditan Perbankan Nasional", Makalah, Fakultas Hukum Universitas Airlangga Surabaya, 1998

Poeseoko, Herowati. Parate execcutie Obyek Hak Tanggungan (inkonsistensi, Konflik Norma dan Kesesatan Penalaran dalam UUHT), Yogyakarta: LaksBang PRESSind, 2008

Ramelan, Eman. "Pidato Pengukuhan : Asas Pemisahan Horizontal Dalam Hukum Tanah Nasional", September 13, 2018

Rubiati, Betty. Pujiwati, Yani. Djakaria, Mulyani. "Asas Pemisahan Horizontal Dalam Kepemilikan Hak Atas Tanah Dan Bangunan Satuan Rumah Susun Bagi Masyarakat Berpenghasilan Rendah (MBR)", Jurnal Sosiohumaniora 17, no. 2 (2015): 1-148. 

Hatta Isnaini Wahyu Utomo, Perlindungan Hukum Bagi Kreditur ...

Sjahdeni, Sutan Remy. Hak Tanggungan Asas-Asas Ketentuan-Ketentuan Pokok Dan Masalah Yang Dihadapi Oleh Perbankan, Bandung: Alumni, 1999

Sudiyat, Imam. Hukum Adat Sketsa Asas, Yogyakarta: Liberty, 1981

Sutantio, Retnowulan. Penelitian Tentang Perlindungan Hukum Eksekusi Jaminan Kredit, Jakarta: Badan Pembinaan Hukum Nasional (BPHN), 1999

Usman, Rachmadi. Aspek-aspek Hukum Perbankan di Indonesia, Jakarta: Gramedia Pustaka Utama, 2001

Utomo, Hatta Isnaini Wahyu. Memahami Pelaksanaan Tugas Jabatan Pejabat Pembuat Akta Tanah, Yogyakarta: Phoenix Publisher, 2019

---. "Hukum Tanah Nasional : Bahan Diskusi Dalam Persiapan Menghadapi Ujian Pejabat Pembuat Akta Tanah 2017", Makalah, disampaikan pada acara Persiapan Menghadapi Ujian PPAT 2017, Universitas Narotama Surabaya, Oktober 2017 